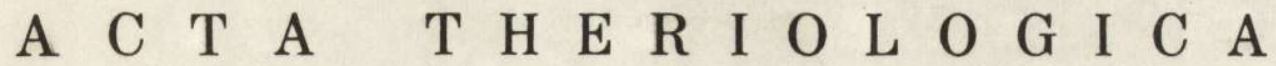

VOL. XVII, 21: $271-294$.

BIAŁOWIEŻA

October, 1972

\author{
Marek GĘ B C Z Y N SK I, Andrzej G ÓRECK I \\ \& Andrzej DROŻD Ż
}

\section{Metabolism, Food Assimilation and Bioenergetics \\ of Three Species of Dormice (Gliridae)}

\author{
[With 7 Tables \& 7 Figs.]
}

\begin{abstract}
Oxygen consumption was determined in the fat dormouse, forest dormouse and common dormouse in late spring and early summer, and in autumn. Since 24-hr measurements were obtained the activity of these animals could be also evaluated. Moreover, food consumption of the fat dormouse was determined in spring. Considerable seasonal differences metabolic rate were observed. Cost of maintenance as estimated from food consumption is slightly higher than that calculated from oxygen consumption. The daily energy budget $(D E B)$ was computed for all 3 species. $D E B$ of hibernating rodents in the period of their active life appears identical with that of non-hibernating animals. In an attempt to estimate annual cost of maintenance it was calculated that in the half-year hibernation period, these species consume
\end{abstract} less than $10 \%$ of their total annual energy budget.

\section{CONTENTS}

1. Introduction

272

Material and methods . . . . . . 272

3. Results . . . . . . . . . . . . . . . . . . . . 273

3.1. Fat dormouse .

3.2. Forest dormouse . . . . . . . . . . . . . . . . . 277

3.3. Common dormouse . . . . . . . . . . . . . . 278

3.4. Food consumption in the fat dormouse . . . . . . . . . 279

4. Discussion . . . . . . . . . . 282

4.1. Daily energy budget . . . . . . . . . . . . . . . 283

4.1.1. Fat dormouse . . . . . . . . . . . . . . . 284

4.1.2. Forest dormouse . . . . . . . . . . . . . . 286

4.1.3. Common dormouse . . . . . . . . . . . . . 286

4.2. Food consumption and respiration . . . . . . . . 287

4.3. Comparison of $D E B$ in hibernating and non-hibernating rodents : $\quad 287$

4.4. Annual energy budget . . . . . . . . . . . . . . 288

References . . . . . . . . . . . . . . . . . . . 292

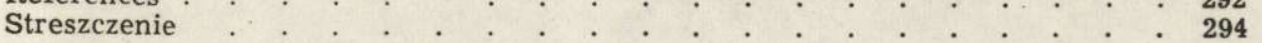

Acta theriol. 18

[271] 


\section{INTRODUCTION}

Dormice (Gliridae) differ from the majority of rodents not only in their ability to hibernate but also in their arboreal life style. For this reason trapping them is difficult and they have been insufficiently investigated although their numbers may be high in various areas ( $\mathrm{Li}$ khachev, 1954; Rosický \& Kratochvil, 1955; Pielowski \& Wasilewski, 1960; Golodushko \& Padutov, 1961; Ang e r m a n n, 1963). Physiological studies carried out hitherto principally concerned their hibernation (cf. Kayser, 1961) and energy requirements during this period. Only fragmentary data are available on metabolism of active dormice ( $\mathrm{K}$ a y s e r, 1939). For this reason an attempt was made to determine oxygen consumption and food requirement of these animals in late spring (May) and early summer (June), and for comparison also in autumn (November - October). This allowed calculation of the daily energy budget for comparison with that of nonhibernating rodents. Moreover, the annual energy requirement of dormice has been calculated.

\section{MATERIALS AND METHODS}

The investigations were carried out on 26 fat dormice, Glis glis (Linnaeus, 1776), 5 forest dormice, Dryomys nitedula (P a 11 a s, 1779), and 12 common dormice, Muscardinus avellanarius ( $\mathrm{L}$ in $\mathrm{n}$ a e $\mathrm{us}, 1758$ ). Fat and forest dormice were captured in eastern Poland (Bialowieża National Park, $52^{\circ} 42^{\prime} \mathrm{N}, 23^{\circ} 51^{\prime} \mathrm{E}$ ) and southern Poland (surroundings of Krakow, $50^{\circ} 47^{\prime} \mathrm{N}, 19^{\circ} 44^{\prime} \mathrm{E}$ ), while common dormice came from central Poland (Kampinoska Forest, $52^{\circ} 20^{\prime} \mathrm{N}, 20^{\circ} 44^{\prime} \mathrm{E}$ ). Most experiments were accomplished within a few days after capture of the animals, but in some cases dormice stayed in the laboratory several weeks before the measurements. They were fed hempseed, hazel-nuts, jam, carrots and apples. Natural daily light rhythm was maintained and the temperature of room ranged from 16 to $20^{\circ} \mathrm{C}$.

Oxygen consumption was used as the indication of heat production rate, and this was measured in a closed-circuit respiratory metabolism apparatus. For daily runs $(A D M R)$ a 10.81 chamber and a Morrison respirometer (M orris on \& Grodziński, 1968) were used, while for short-term measurements $(R M R)$ a Kalabukhov-Skvortzov apparatus with 11 chamber was employed (G ę bczy ński, 1963; Gór e c k i, 1968).

Food consumption, digestibility and assimilation in G. glis were determined by the balance method ( $\mathrm{Dr}$ oz d $\dot{z}, 1968 \mathrm{a}$ ). The animals were supplied for 14 days either with hazel-nuts alone, which constitute their preferred food (Holišova, 968 ), or additionally the diet was supplemented with carrot. Both in the initial period and in the main experiment, food was supplied ad libitum. The main experiment extended to 5 or 6 days. During this time the animals were isolated in metabolism cages (D rożd $\dot{z}$ et al., 1971). Feces and urine were quantitatively collected daily, and combusted in calorimetric bomb after desiccation (D r ożd ż, $1968 \mathrm{~b})$. All feeding experiments were carried out at $20^{\circ} \mathrm{C}$ under $12 \mathrm{D}: 12 \mathrm{~L}$ using in the first series of the experiment 8 , and in the second series 7 fat dormice. 


\section{RESULTS}

\subsection{Fat Dormouse}

Chemical thermoregulation. Both in spring and autumn the resting metabolic rate $(R M R)$ was determined at different ambient temperatures in the range from 0 to $25^{\circ} \mathrm{C}$ (Fig. 1). In spring at $10^{\circ} \mathrm{C}$ the level of oxygen consumption was exactly two times higher than at $20^{\circ} \mathrm{C}$. A change of temperature by $1^{\circ} \mathrm{C}$ in this range caused an increase of oxygen consumption by $0.11 \mathrm{ccm} / \mathrm{g} \mathrm{hr}$. A similar change of metabolism occurred in the range of 0 to $10^{\circ} \mathrm{C}$.

In autumn oxygen consumption was found to be higher than in spring (Fig. 1), and the differences between seasons at ambient tempe-

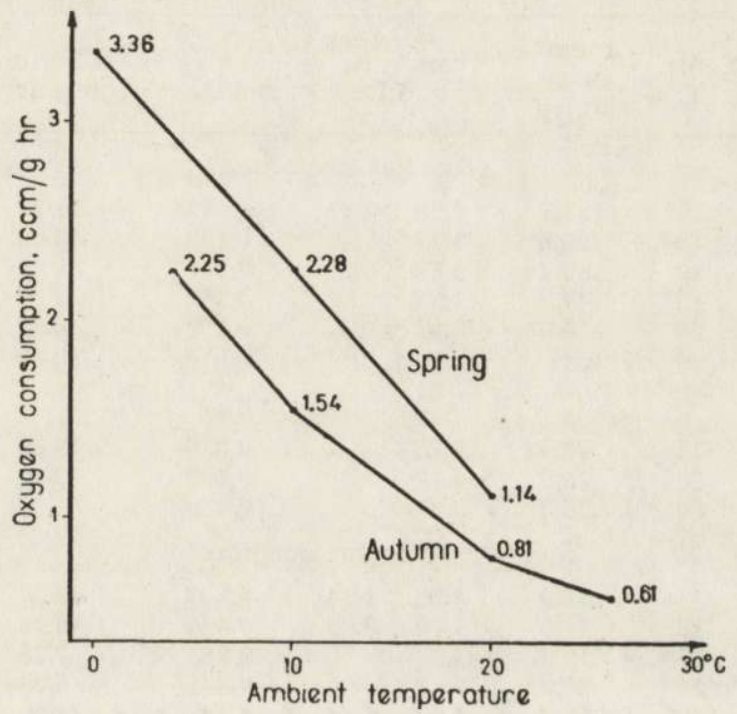

Fig. 1. Resting metabolism rate at different temperatures in Glis glis in spring and autumn.

rature below $20^{\circ} \mathrm{C}$ are highly significant $(\mathrm{P}<0.01)$. Nevertheless, the rate of change of metabolism related to changes of ambient temperature is also high in autumn and amounts to $0.09 \mathrm{ccm} / \mathrm{g} \mathrm{hr}$ per $1^{\circ} \mathrm{C}$ at 4 to $20^{\circ} \mathrm{C}$. At higher temperatures this rate decreases considerably, barely reaching $0.03 \mathrm{ccm} / \mathrm{g} \mathrm{hr}$ per $1^{\circ} \mathrm{C}$.

Average daily metabolic rate $(A D M R)$. $A D M R$ determinations were carried out at 15 and $20^{\circ} \mathrm{C}$, in both spring and autumn, and additionally at $30^{\circ} \mathrm{C}$ in autumn (Table 1). Spring $A D M R$ of fat dormice at $15^{\circ} \mathrm{C}$ is higher by $37 \%$ compared with $A D M R$ determined at $20^{\circ} \mathrm{C}$. The dif- 
ference in the average daily oxygen consumption resulting from the temperature gradient is similar to that determined in short-term measurements of oxygen consumption $(R M R)$ for the same temperatures and amounts to $0.12 \mathrm{ccm} / \mathrm{g} \mathrm{hr}$ per $1{ }^{\circ} \mathrm{C}$.

In autumn $A D M R$ at $15^{\circ} \mathrm{C}$ is higher by $47 \%$ from $A D M R$ at $20^{\circ} \mathrm{C}$, and the latter value lower by $35 \%$ from that at $30^{\circ}$ (Table 1 ). In this season a change of $A D M R$ caused by differences in ambient temperatures is exactly the same as in $R M R$ measurements. $A D M R$ in autumn is lawer than in spring both at 15 and $20^{\circ} \mathrm{C}$, the difference being statistically significant $(\mathrm{P}<0.01)$.

Table 1

Mean daily oxygen consumption by dormice in spring and autumn.

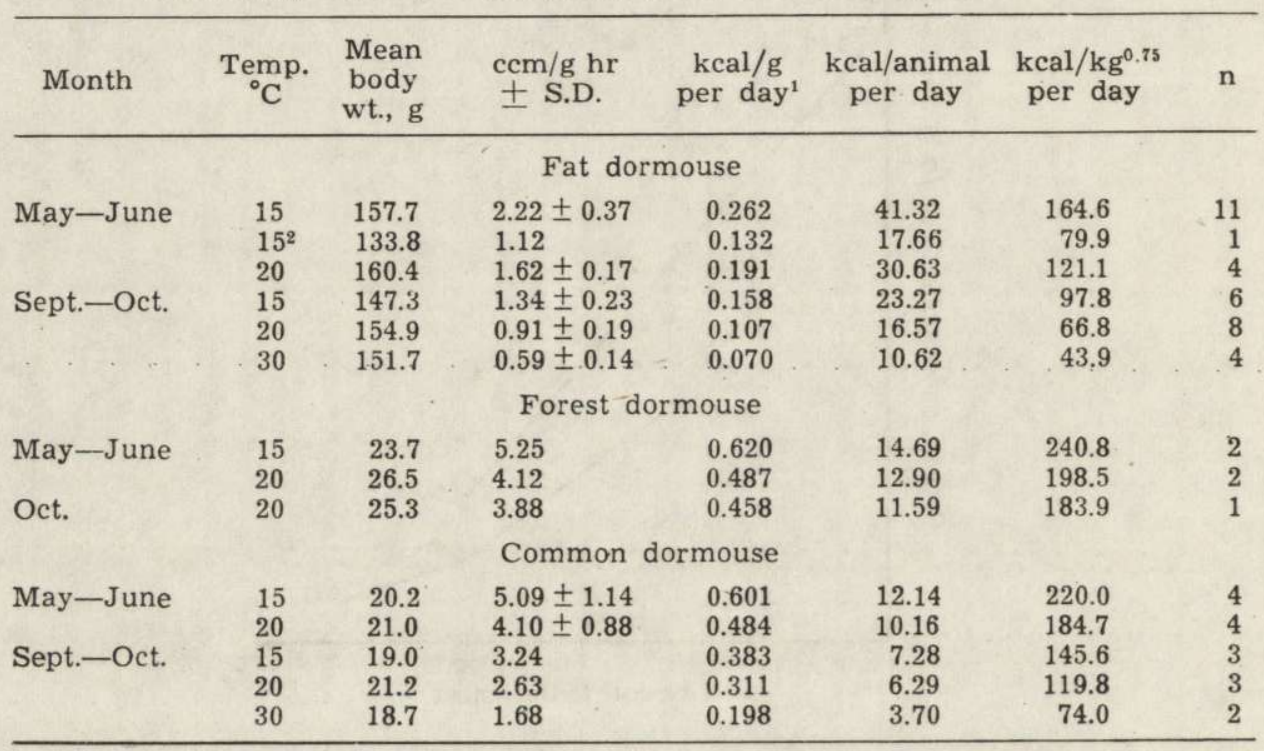

1 It was assumed that $R Q$ equals 0.9 and hence the caloric coefficient of oxygen amounts to $4.924 \mathrm{kcal} / 1$. 2 One individual examined for $75 \mathrm{hr}$ non-stop (see Fig. 3). During each day it was torpid 15 hours and for 9 hours it was active.

$\mathrm{C}$ ircadian $\mathrm{rhyth}$. Considerable changes in the rate of oxygen consumption are observed during $24 \mathrm{hr}$ period, and a definite rhythm is visible. This rhythm is largely independent of measurement temperatures and the pattern of activity shows one definite peak (Fig. 2). Increased activity begins before nightfall but the maximum oxygen consumption corresponds to the first hours of darkness. Subsequently a prompt decrease of activity is observed with a minimum occurring before sunrise. The period of low activity correspond in all cases to morning hours (Fig. 2). Although the period of increased activity includes 
evening hours, and activity is reduced before daybreak, nocturnal activity still prevails. The amount of oxygen consumed during the night was always 33 to $45 \%$ higher in the daytime.

Individual fat dormice in laboratory show considerable deviations in daily rhythm from the pattern described above. During the day the fall into a state of torpor, and awake from it for only a few hours. The rhythm of oxygen consumption in such an individual was determined experimentally and compared with the rhythm of another animal which

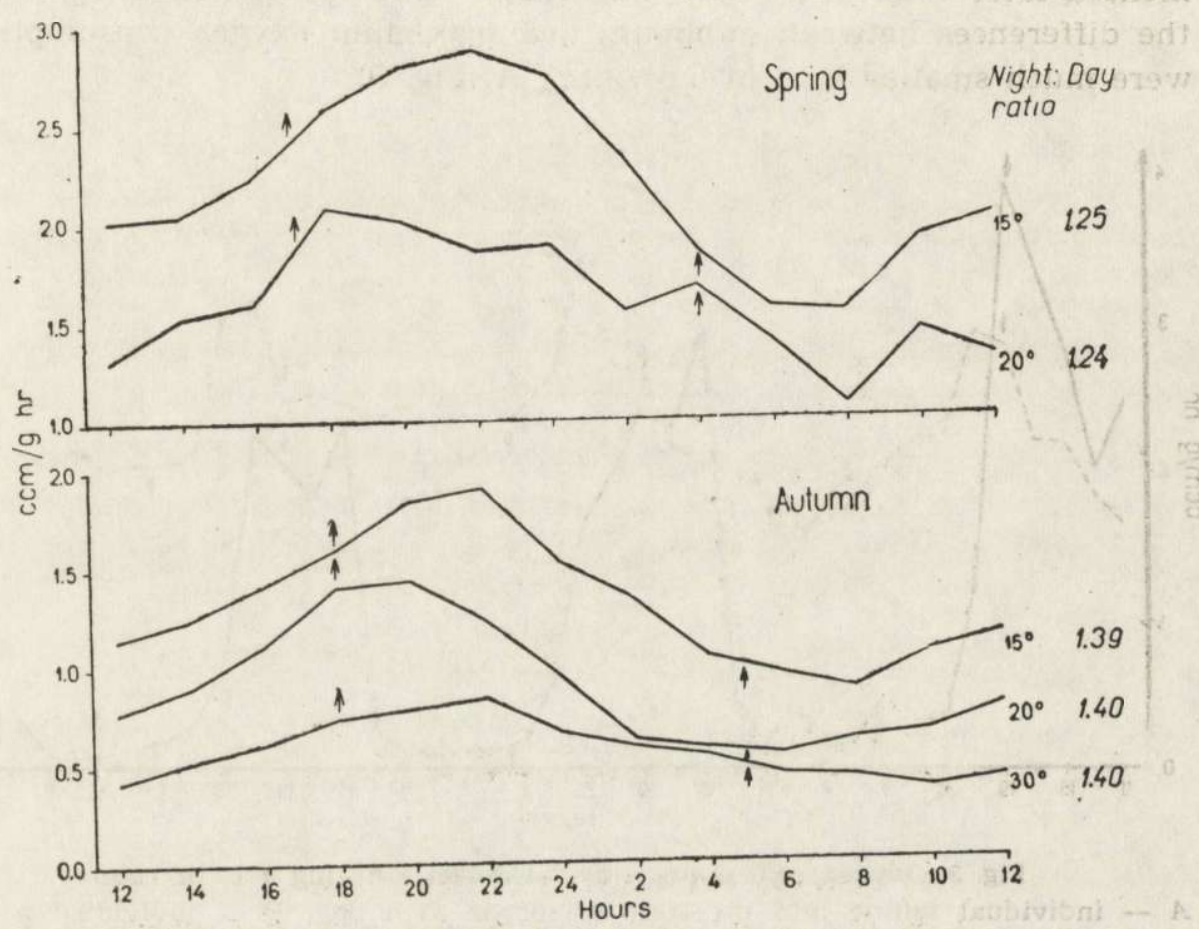

Fig. 2. Circadian rhythm of oxygen consumption in fat dormouse (G. glis) in spring and autumn.

Arrows indicate the beginning and end of night.

did not fall into torpor, although experiencing considerably reduced activity. In order not to disturb the natural rhythm of activity of the fat dormice, measurements were continued non-stop for 3 days (Fig. 3).

The two oxygen consumption curves show a definite peak during 24-hour period. However, the dormouse falling into torpor (individual A) awoke during the day and immediately consumed more oxygen, hence the period of increased activity begins (Fig. 3). This occurred at exactly 3 p.m. throughout experiment. The period of increased oxygen con- 
sumption lasted 9 hours. During this time average oxygen consumption was $2.26 \mathrm{ccm} / \mathrm{g} \mathrm{hr}$, whereas in the remaining 15 hours, it dropped to $0.25 \mathrm{ccm} / \mathrm{g} \mathrm{hr}, 9$ times lower. The maximum oxygen consumption fell in this individual during dusk and early night hours, and this was followed by a decrease equally sharp as the initial rise (Fig. 3.)

The period of maximum oxygen consumption in individual $B$, which did not become torpid, correspond to night-time consumption beginning at dusk. Hence the period of increased activity in the individual $B$ commenced later than in $A$. Also, maximum consumption was delayed and the differences between minimum and maximum oxygen consumptions were much smaller than in individual $A$ (Fig. 3).

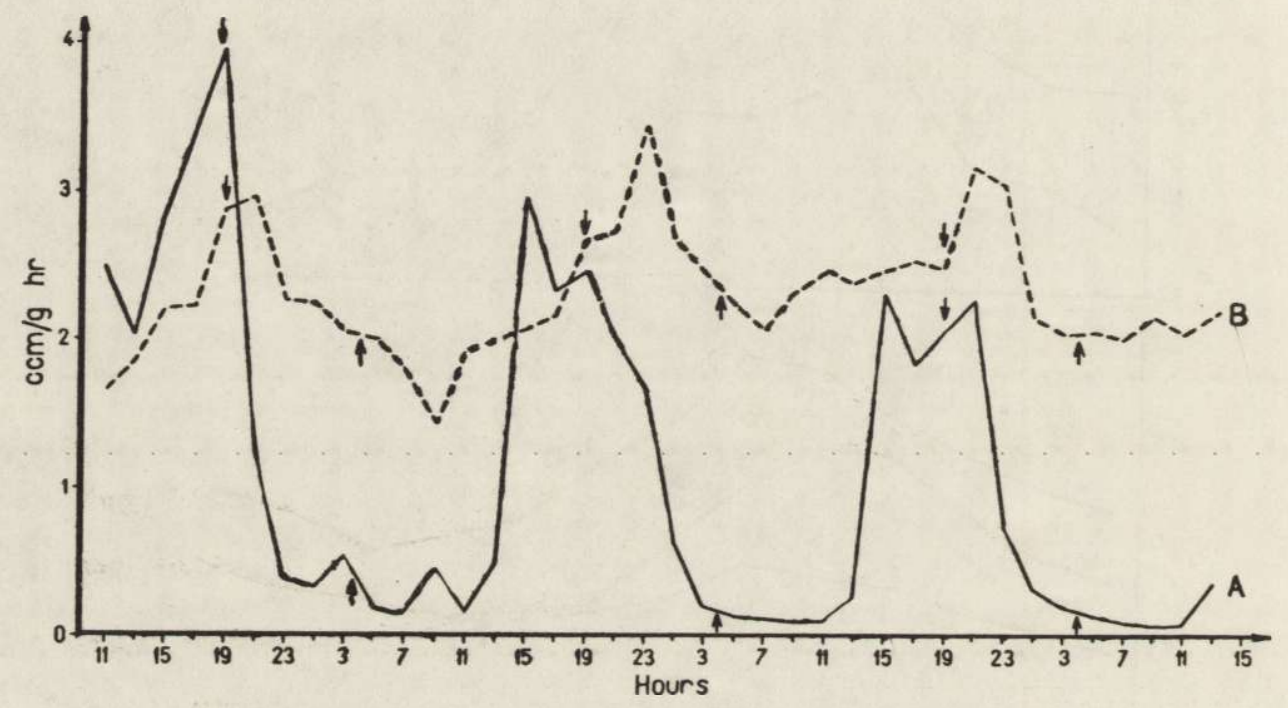

Fig. 3. Oxygen consumption by fat dormice during a $75 \mathrm{hr}$ run.

$A$ - individual falling into the state of torpor each day, $B-$ individual active all the time.

Due to the uninterrupted three-day measurements it was also possible to establish that the conditions of this experiment did not affect the daily rhythm and the total activity of the animals examined. In all consecutive days the oxygen consumption rhythm was well retained, although the total amount of oxygen consumed by fat dormouse $A$ during its period of activity was higher the first day than in the two remaining days. This is probably related to arousing the animal while weighing it before the start of measurements. Dormouse $B$, however, showed no considerable changes of oxygen consumption in consecutive days. 


\subsection{Forest Dormouse}

Since only a few forest dormouse were captured the experiments were limited to 5 individuals. In spring $A D M R$ was measured at 15 and $20^{\circ} \mathrm{C}$, in autumn - only at $20^{\circ} \mathrm{C}$. $R M R$ could be determined at different ambient temperatures also only in the spring.

$\mathrm{Chemical}$ thermoregulation. The change of metabolic rate associated with differences of ambient temperature in the forest dormouse is even more distinct than in the fat dormouse since between 2 and $20^{\circ} \mathrm{C}$ mean oxygen consumption changes by $0.14 \mathrm{ccm} / \mathrm{g} \mathrm{hr}$ per $1{ }^{\circ} \mathrm{C}$ (Fig. 4). Above $20^{\circ} \mathrm{C}$ this value decreases to 0.07 . Hence in both dormice

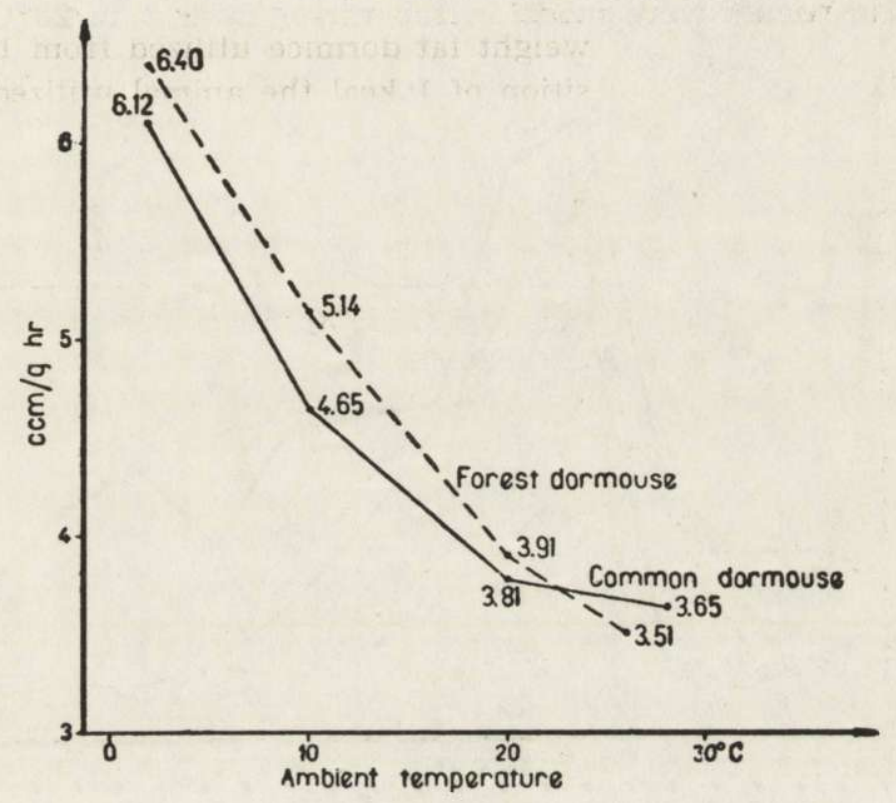

Fig. 4. Resting metabolism rate at different temperatures in Dryomys nitedula and Muscardinus avellanarius in spring.

species a strong increase in oxygen consumption was observed below $20^{\circ} \mathrm{C}$. This reaction is considerably smaller in more favourable thermal conditions.

$A D M R$ of forest dormouse is slightly higher in spring than in autumn (Table 1). At $20^{\circ} \mathrm{C}$, employed in both seasons, this difference amounts to $6.2 \%$. In spring $A D M R$ determined at $15^{\circ} \mathrm{C}$ is higher by $27.4 \%$ than at $20^{\circ} \mathrm{C}$. 
Daily $\mathrm{rhythm}$ of oxygen consumption by the forest dormouse shows a clear maximum (Fig. 5), similar to that in the fat dormouse. In spring the period of increased activity begins later during the day than in autumn, but it also terminates later. In both seasons the increased activity occurs before dusk, and the reduction - before sunrise. Hence the forest dormouse may be regarded as a species crepuscular and nocturnal (Fig. 5).

\subsection{Common Dormouse}

Chemical thermoregulation. This character was determined in the spring, because only then were sufficient animals available. The measurements were made in the range from 2 to $28^{\circ} \mathrm{C}$. Metabolic

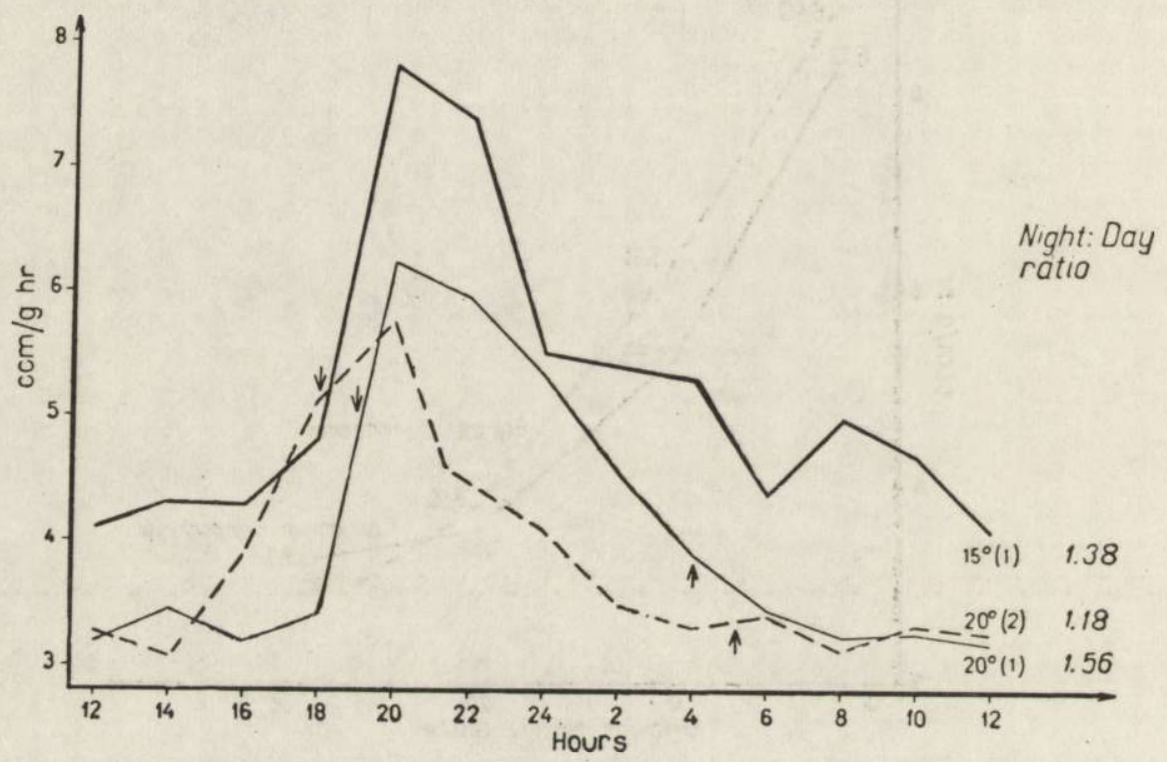

Fig. 5. Circadian rhythm of oxygen consumption by forest dormouse (D. nitedula) in spring (1) and autumn (2).

change in this temperature interval is not uniform (Fig. 4). The most marked change was found between 2 and $10^{\circ} \mathrm{C}\left(0.18 \mathrm{ccm} / \mathrm{g} \mathrm{hr}\right.$ per $\left.1^{\circ} \mathrm{C}\right)$. From 10 to $20^{\circ} \mathrm{C}$ this value was reduced to 0.07 , and above $20^{\circ} \mathrm{C}$ was: almost completely cancelled. Hence chemical thermoregulation in the common dormouse is similar to that in forest dormouse, but more pronounced at lower temperatures.

The $A D M R$ value is higher in spring than in autumn, similarly to that of other dormice species. This difference is, however, particularly strong 
because in spring $A D M R$ at 15 and $20^{\circ} \mathrm{C}$ is higher than in autumn by approximately $56 \%$ (Table 1). It was also possible to conclude that in autumn $A D M R$ at $15^{\circ} \mathrm{C}$ is $23 \%$ higher than at $20^{\circ} \mathrm{C}$, while the difference between 20 and $30^{\circ}$ is $26 \%$ only.

Circadian $r h y t h m$. The activity pattern of this species can be described as the night pattern with one strongly pronounced maximum (Fig. 6). In spring the period of increased activity was more clearly

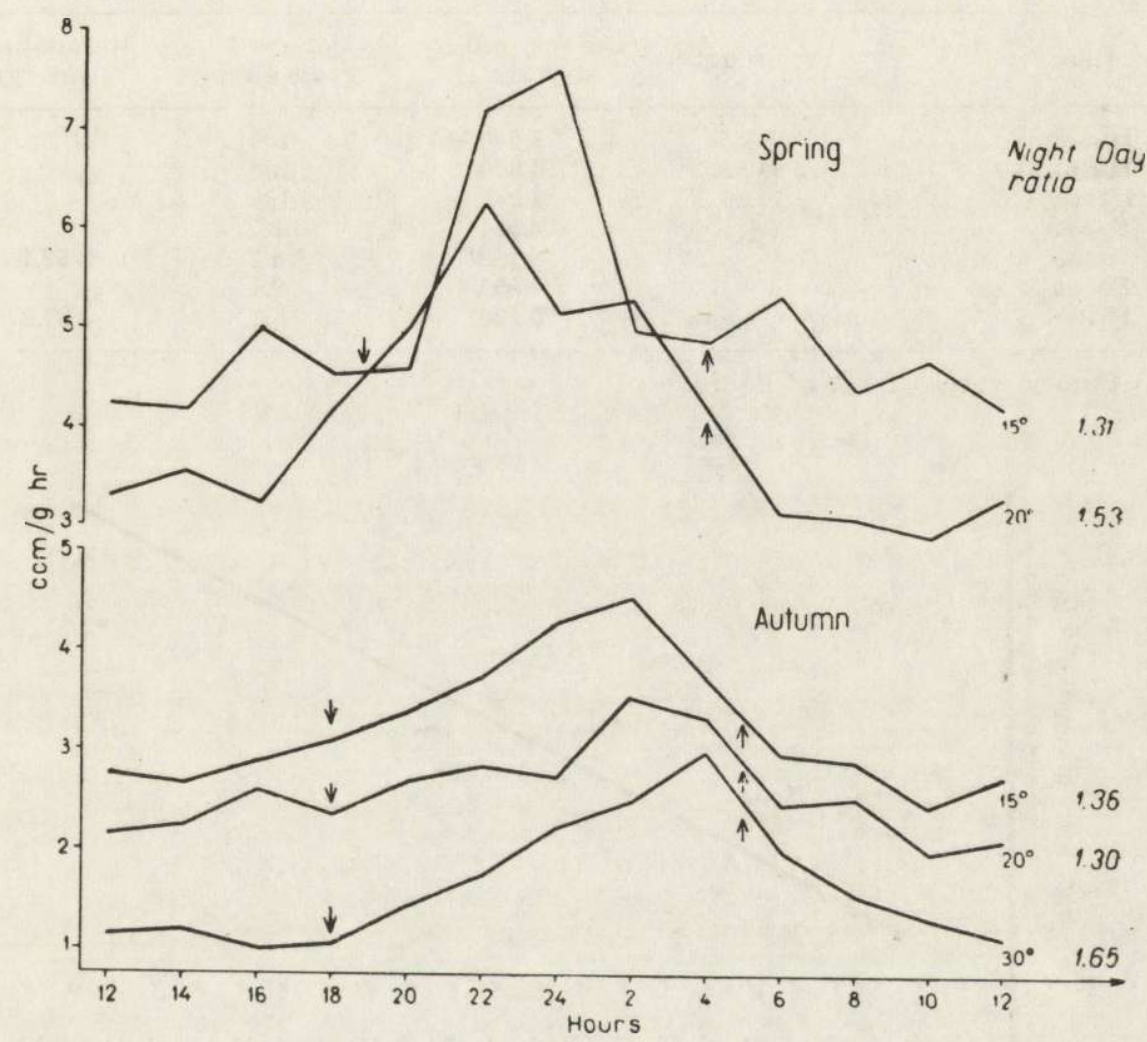

Fig. 6. Circadian rhythm of oxygen consumption by common dormouse (M. avellanarius) in spring and autumn.

visible than in autumn when the maximum fell for the second part of night instead of midnight. The common dormouse increases its activity only after nightfall and terminates it before dawn.

\subsection{Food Consumption in Fat Dormouse}

Feeding experiments were carried out on fat dormice in the spring (April) to verify respirometric determination. The cost of maintenance 
were calculated from the metabolizable energy $(M E)$ consumed, i.e., assimilation. The digestibility of hazel-nuts was $91.3 \pm 0.4 \%$, and in a mixture of hazel-nuts and carrots it amounted to $90.9 \pm 0.5 \%$ of gross energy (consumption) and was characterized by minimum variability

Table 2

Coefficient of digestibility and food utilization by fat dormice.

\begin{tabular}{ccccc}
\hline Item & Dry mass $\%$ & $\begin{array}{c}\text { Caloric value/g } \\
\text { dry weight }\end{array}$ & $\begin{array}{c}\text { Per cent of } \\
\text { gross energy }\end{array}$ & $\begin{array}{c}\text { Metabolizable } \\
\text { energy }\end{array}$ \\
\hline I Hazelnuts & 94.65 & 8.030 & 100 & \\
II Hazelnuts & 94.65 & 8.030 & 100 & \\
Carrot & 14.25 & 3.987 & 100 & 88.1 \\
I Feces & - & 4.591 & 8.7 & 8.2 \\
Urine & - & $0.153^{1}$ & 9.1 & 8.8 \\
II Feces & - & 4.555 & 3.1 & $88^{1}$ \\
Urine & - & $0.128^{1}$ & & \\
\hline
\end{tabular}

1 Caloric value of $1 \mathrm{~g}$ of liquid.

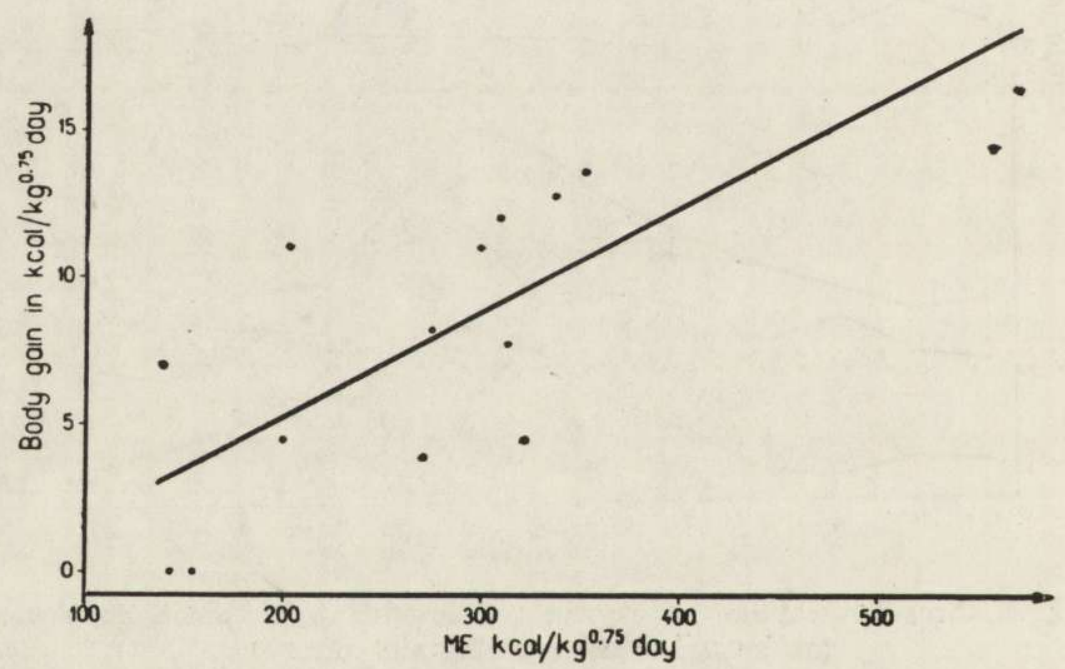

Fig. 7. Relation between intake of metabolizable energy $(M E)$ and body gain expressed in $\mathrm{kcal} / \mathrm{kg}^{0.75}$ day. $y=-1.627+0.035 x$.

(C.V. $=0.4 \%)$. Metabolizable energy of the food supplied amounted to $88.1 \pm 0.7 \%$ of the gross energy for hazel-nuts and $87.8 \pm 0.8 \%$ for mixed hazel-nuts and carrots (Table 2).

Fat dormice consumed the two foods in amounts considerably exceeding their daily energy requirements. The amount of $M E$ consumed dailv 


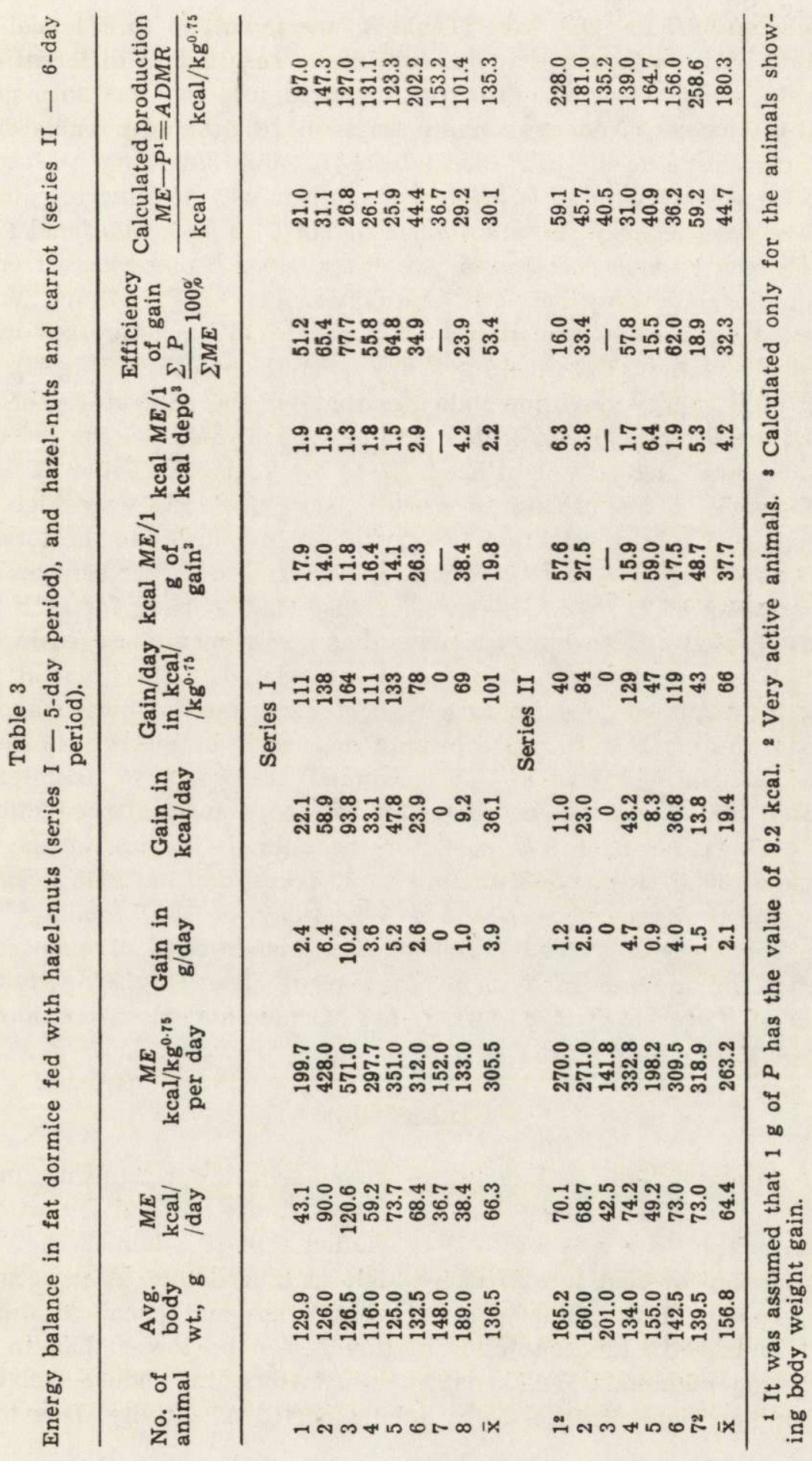


ranged from 36.7 to $120.6 \mathrm{kcal}$ (Table 3), i.e. from 133 to $571 \mathrm{kcal} / \mathrm{kg}^{0.75}$ day. Such large differences in energy intake resulted in different daily body gain, which varied from 0 to $10 \mathrm{~g}$. Assuming that fat dormice deposiled the excess of energy as adipose tissue [this being possible due to a high caloric value of their food (Table 2), and assuming the caloric value of $1 \mathrm{~g}$ body gain as equal to $9.2 \mathrm{kcal}$, it was possible to calculate that their daily energy retention varied from 0 to $94 \mathrm{kcal} /$ animal (Table 3 ). The highest value corresponds to $16.4 \mathrm{kcal} / \mathrm{kg}^{0.75}$ of deposited energy per day. A relationship between assimilation per $\mathrm{kg}^{0.75}(\mathrm{X})$ and energy retention expressed in kcal deposited per $\mathrm{kg}^{0.75}(\mathrm{Y})$ is expressed by the regression equation: $Y_{M E} \mathrm{kcal} / \mathrm{kg}^{0.75}$ day $=-1.627+0.035 \mathrm{X}$ (Fig. 7).

Such high energy retention indicates that for the gain of $1 \mathrm{~g}$ of body weight fat dormice utilized from 12 to $59 \mathrm{kcal}$ of $M E$, i.e. for the deposition of $1 \mathrm{kcal}$ the animal utilized 1.2 to $6.4 \mathrm{kcal} M E$ (Table 3). Hence the efficiency of the process of growth is in this case very high. The relationship of total production $(P)$ expressed in calories to the total $M E$ taken up in the period of experiment and expressed in per cent amounts to a maximum of $77.7 \%$ in the extreme case $(43.7 \%$ mean for both types of food) (Table 3). Such high efficiency has never been observed in other animals. Of course the results obtained are related to the great attractivity of the supplied food, to rather short experimental period and unusual abilities of fat dormice to prompt deposition of reserve substances. Despite such large excess of $M E$ consumed the costs of maintenance calculated from the difference between $M E$ consumed and production $(P)$ varied in a rather narrow range. For the animals staying at the temperature of $20^{\circ} \mathrm{C}$ these costs amount to $30.1 \mathrm{kcal} /$ day or $135.3 \mathrm{kcal} / \mathrm{kg}^{0.75}$ day for the first type of food and $44.7 \mathrm{kcal} /$ day, or $180.3 \mathrm{kcal} / \mathrm{kg}^{0.75}$ day for the second type of food (Table 3). The higher costs of maintenance estimated for the second type of food result from higher activity of animals in these experiments when fat dormice stayed in considerably larger cages.

\section{DISCUSSION}

The estimation of efficiency of physiological mechanisms in the animals hibernating during the period of their life activity varies to a great extent. Kayser (1939) concluded that in summer the short-term reaction to cold is extremely high in hibernators. Also according to $\mathrm{Kalabukhov}(1960)$ the metabolic rate and chemical thermoregulation level in hibernators is in this period no lower than in non-hibernating mammals. This enables hibernators to endure relatively sharp ambient temnerature drops during period of activity Due to this 
fact such physiological processes as reproduction, growth and moulting occur normally, as well as accumulation of energy reserves for the period of hibernation. Nevertheless, the hibernators have their own characteristics even during aestival activity state ( $\mathrm{K}$ a y s e r, 1965; S outh \& Hous e, 1967). Hiberna ors, for example, show greater body temperature fluctuations in comparison with other mammals, their mean body temperature being slightly lower ( $\mathrm{E}$ is entraut, 1956). It was also found that in summer some individuals became torpid (cf. Fig. 3). This phenomenon was observed in natural conditions as well, as reported for Muscardinus avellanarius ( $\mathrm{L} \mathrm{k} \mathrm{h} \mathrm{a} \mathrm{ch} \mathrm{e}, 1965$ ). The number of $M$. avellanarius individuals found in torpor depends on season, and in the spring $41 \%$ of animals were observed in this state, in summer $12 \%$, and in autumn $34 \%$. The phenomenon shows also a clear circadian rhythm and between hours 7 and 9 a.m. $57 \%$ individuals were found asleep, while between 1 and 3 p.m. only $12 \%$ ( $\mathrm{Lik} \mathrm{h} \mathrm{a} \mathrm{c} \mathrm{hev,} \mathrm{1965).}$

\subsection{Daily Energy Budget}

The energy budget can be calculated on the basis of any measure describing the energy requirement of a given species. The most useful, however, is the average daily metabolic rate $(A D M R)$ which requires the lowest number of corrections (Grodziński \& Górecki, 1967).

Table 4

Air temperature $\left({ }^{\circ} \mathrm{C}\right) 2 \mathrm{~m}$ above the ground level in Tilio-Carpinetum in Białowieża National Park at $1 \mathrm{hr}$ intervals (1958-1961).

\begin{tabular}{|c|c|c|c|c|c|c|c|c|c|c|c|c|c|}
\hline Month & 18 & 19 & 20 & 21 & 22 & $\begin{array}{c}\text { Hours. } \\
\qquad 23\end{array}$ & 24 & 1 & 2 & 3 & 4 & 5 & 6 \\
\hline May & 13.8 & 12.5 & 10.8 & 9.5 & 8.5 & 8.0 & 7.5 & 6.9 & 6.7 & 6.3 & 6.1 & 6.4 & 7.6 \\
\hline June & 16.4 & 15.6 & 14.4 & 13.4 & 12.2 & 11.6 & 11.0 & 10.6 & 10.2 & 9.9 & 9.9 & 10.3 & 11.3 \\
\hline Sept. & 11.0 & 10.0 & 9.1 & 8.5 & 8.1 & 7.7 & 7.4 & 7.3 & 7.0 & 6.9 & 6.8 & 6.7 & 6.8 \\
\hline Oct. & 7.2 & 6.5 & 6.1 & 5.8 & $5 . \overline{3}$ & 5.2 & 5.0 & 4.8 & 4.6 & 4.5 & 4.4 & 4.4 & 4.3 \\
\hline
\end{tabular}

Also, in the case of Gliridae species discussed here, the budget is based on $A D M R$ measurements. It should be added that at present our knowledge concerning the basal or resting metabolism of these animals is still limited (K a y s e r, 1939, 1965; K a y ser \& Hildwei $n, 1966)$.

There is no doubt, however, that in summer aroused hibernators have a very considerable chemical thermoregulation ability (K a y s e r, 1965), and this was confirmed in the present study. For conversion of oxygen consumption into kilocalories the respiratory quotient $(R Q)$ was assumed 
to be 0.9 , hence slightly higher than in non-hibernating rodents. $\mathrm{K}$ a $\mathrm{y}-$ s e r (1961) reported that in hibernating hibernators $R Q$ is equal to 0.7 and during arousal increases from 0.8 to 1.0 . At $R Q$ equals 0.9 the caloric equivalent of oxygen reaches $4.924 \mathrm{kcal} / \mathrm{l}$.

One of the essential corrections to $A D M R$ concerns increased chemical thermoregulation during activity out of nest. All species of the investigated Gliridae to date are active at night but in some cases they leave the nest at dusk. The period of activity out of the nest lasts for 7 to 9 hours (Ostermann, 1956; Saint Girons, 1960, 1965; Saint Girons \& Lenkiewicz, 1965; Walhovd, 1971). For this reason the ambient temperature during the period of out-of-the-nest activity of Gliridae was taken into consideration. The values of temperature determined at the level of $2 \mathrm{~m}$ above ground in a Tilio-Carpinetum stand of the Białowieża Forest are reported in Table 4. On this basis mean temperatures in the period of activity of studied rodent species were calculated.

No data are available on the exact temperature inside dormice nests. For other small non-hibernating mammals inhabiting the temperate zone the temperature of $20^{\circ} \mathrm{C}$ was generally accepted ( $\mathrm{G} \mathrm{ę} \mathrm{bczy} \mathrm{n} \mathrm{s} \mathrm{ki,}$ 1966; Grodziński \& Górecki, 1967; Górecki, 1968, 1969). However, in summer the nests of the Gliridae are found in trees it may be assumed that they are subjected to greater changes of temperature. Hence data on $A D M R$ determined both at 20 and $15^{\circ} \mathrm{C}$ were used for the calculations in Table 7 (see p. 290).

\subsubsection{Fat dormice}

In summer and spring fat dormice are active an average of 8 hours a day (O s t e r m a n n, 1956, data reported here). In autumn the activity extends for similar interval of time (K a y s r \& Hildwein, 1966). In these hours (from 8 p.m. to 4 a.m.) the mean air temperature $2 \mathrm{~m}$ above ground in May is $7.8^{\circ} \mathrm{C}$ and in June $11.5^{\circ} \mathrm{C}$, hence the mean value in $9.6^{\circ} \mathrm{C}$. After rounding off this value the correction for out-of-the-nest thermoregulation as calculated for $10^{\circ} \mathrm{C}$ by extrapolating the $A D M R$ value determined at $15^{\circ} \mathrm{C}$ (Table 1). Such calculation is justified by the found value of chemical thermoregulation (Fig. 1), which is rectilinear in the range from 0 to $20^{\circ} \mathrm{C}$. The calculated correction amounts to $8 \times$ $1.20 \mathrm{ccm} / \mathrm{g} \mathrm{hr}=9.60 \mathrm{ccm} / \mathrm{g} 8 \mathrm{hr}$ per day. The reaction of the fat dormouse to cold is strong and thus the correction reaches a relatively high value. Altogether the fat dormouse consumes $38.29 \mathrm{kcal} /$ day (Table 5).

Other essential corrections include an increased energy requirement in pregnant and lactating females. For a whole population of non-hiber- 
nating rodents this correction amounts to $6.5 \%$ in the bank vole $(\mathrm{K} \mathrm{a} \mathrm{c} \mathrm{z}$ marski, 1966), and about $10 \%$ in common vole ( $T$ rojan \& Wojc i e chowska, 1967; Migula, 1969). On the other hand, however, a decreased rate of metabolism due to social thermoregulation in animals huddling in the nest should be taken into consideration. Since this value may reach approximately $14 \%$ of the daily energy requirements in rodents (G ę bczyński, 1969) it was assumed that these two corrections cancel each other. In such a case the daily energy requirement is equal to $A D M R$ plus correction for out-of-the-nest activity (Table 5).

The daily energy budget of fat dormice was also calculated on basis of $A D M R$ determined at $15^{\circ} \mathrm{C}$ (Table 5). This budget was found to be $21.2 \%$ higher than the $D E B$ calculated above. Moreover, the daily energy expenses were calculated for an individual which became torpid (cf. Fig.

Table 5

Daily energy budget $(D E B)$ in three species of Gliridae in spring (May-June) and autumn (September-October).

\begin{tabular}{|c|c|c|c|c|c|}
\hline Season & ${ }^{\circ} \mathrm{C}$ & $\begin{array}{l}A D M R \\
\mathrm{ccm} / \mathrm{g} \mathrm{hr}\end{array}$ & $\begin{array}{c}\text { Cost of activity } \\
\mathrm{ccm} / \mathrm{g} \mathrm{hr}^{1}\end{array}$ & $\begin{array}{c}D E B \\
\mathrm{kcal} / \mathrm{g} \text { day }\end{array}$ & kcal/animal day \\
\hline \multicolumn{6}{|c|}{ Fat dormouse } \\
\hline \multirow[t]{3}{*}{ Spring } & 20 & 1.62 & 1.22 & 0.239 & 38.29 \\
\hline & 15 & 2.22 & 0.60 & 0.289 & 45.10 \\
\hline & $15^{2}$ & 1.12 & 0.60 & 0.144 & 22.76 \\
\hline \multirow{2}{*}{ Autumn } & 20 & 0.91 & 1.14 & 0.152 & 23.61 \\
\hline & 15 & 1.34 & 0.71 & 0.186 & 27.44 \\
\hline \multicolumn{6}{|c|}{ Forest dormouse } \\
\hline \multirow[t]{2}{*}{ Spring } & 20 & 4.12 & 2.26 & 0.576 & 15.26 \\
\hline & 15 & 5.25 & 1.13 & 0.664 & 15.76 \\
\hline Autumn & 20 & 3.88 & 1.51 & 0.518 & 13.10 \\
\hline \multicolumn{6}{|c|}{ Common dormouse } \\
\hline Spring & 20 & 4.10 & 1.98 & 0.562 & 11.81 \\
\hline \multirow{3}{*}{ Autumn } & 15 & 5.09 & 0.99 & 0.640 & 12.92 \\
\hline & 20 & 2.63 & 1.52 & 0.371 & 7.86 \\
\hline & 15 & 3.24 & 0.91 & 0.419 & 7.96 \\
\hline
\end{tabular}

${ }_{1}$ In all cases it was assumed that the period of activity outside the nest lasted 8 hours. 2 Fat dormouse torpid 15 hours a day.

3). Its $D E B$ is approximately one half that of an active individual. In this particular case the period of increased oxygen consumption amounted to 9 hours (Fig. 3). It is likely that in the initial period body temperature rose and this was followed by the phase of activity. Hence the correction for increased heat losses due to remaining outside the nest was calculated not for 9 but for 8 hours. In this period oxygen consumption is exactly the same as during activity of fat dormice not falling 
into torpor, thus the correction is also identical. In the remaining period of the day oxygen consumption was decreased to $0.27 \mathrm{cc} / \mathrm{g} \mathrm{hr}$ on the average. After adding the first hour of increased oxygen consumption, when the return to normal body temperature occurred, the $D E B$ amounted to $22.76 \mathrm{kcal} / \mathrm{animal}$ day. Hence the energy consumption in the hypothermic fat dormouse is $50 \%$ lower than in an individual showing smaller amplitude of oxygen consumption during the day. This means a considerable saving of energy and for this reason in unfavourable thermal conditions some individuals fell into the state of torpor also in the summer.

Using $A D M R$ determined at $20^{\circ} \mathrm{C}$ to calculate $D E B$ for the fat dormouse in early autumn (September), $D E B$ amounts to $23.61 \mathrm{kcal} /$ animal day (Table 5). For $A D M R$ measured at $15^{\circ} \mathrm{C} D E B$ increases by $16.2 \%$, hence the difference is of the same order of magnitude as in the analogous case in spring. It should be emphasized that the energy requirement in autumn is much smaller than in spring.

\subsubsection{Forest dormouse}

The forest dormouse, like the fat dormice, is a nocturnal animal, the period of its out-of-the-nest activity ranging from 7 to 9 hours (Ang e rmann, 1963; Smirnov, 1964; Saint Girons \& Lenkiewicz, 1965). The activity of forest dormice shows certain seasonal variations and is highest in the period of reproduction. They have then been observed to be active even during the day ( $\mathrm{S}$ a in t Girons \& Len$\mathrm{kiewicz}, 1965)$. In May and June the time spent outside the nest is 8 hours ( $\mathrm{Sa}$ int Girons \& Lenkiewicz, 1965; data presented here), from 8 p.m. to 4 a.m. During that period the mean air temperature in a Tilio-Carpinetum forest $2 \mathrm{~m}$ above ground level averages $10^{\circ} \mathrm{C}$. The calculated correction for thermoregulation during 8 hours of activity out of the nest constitutes an additional $18.08 \mathrm{ccm} / \mathrm{g}$, and hence for $A D M R$ equal to $4.12 \mathrm{ccm} / \mathrm{g} \mathrm{hr}, 15.26 \mathrm{kcal} /$ animal day (Table 5).

In autumn $D E B$ as similarly calculated for the fat dormouse, amounts to $13.10 \mathrm{kcal} /$ animal day (Table 5), and is thus only slightly lower from the values reported for spring.

\subsubsection{Common dormouse}

Although the daily activity of this species was investigated by $\mathrm{O}$ s t e r$\mathrm{mann}$ (1956) and Likhachev (1965) the length of the period of activity out of the nest remains unknown. Only W a ldhovd (1971) reports that the activity of common dormice begins at sunset and ends some $70 \mathrm{~min}$ before sunrise, thus lasting approximately 8 hours on aver- 
age. The activity of common dormice depends on season and weather. $\mathrm{Likhachev}$ (1965) observed that during unfavourable weather, common dormice, especially those nursing young, do not leave the nest for several consecutive days. Moreover, young individuals are more active than adult, especially in autumn.

Our results (Fig. 6) permit the conclusion that the pattern of daily activity of common dormice is similar to that in the two other species of Gliridae. For this reason it was assumed that common dormice leave the nest for 8 night-time hours, i.e., from 8 p.m. to 4 p.m.; corrected $D E B$ 's are presented in Table 5 .

\subsection{Food Consumption and Respiration}

Since cost of maintenance were estimated by two methods, oxygen consumption and food consumption, it was possible to compare the results. The costs of maintenance of fat dormice determined by respirometry was $30.6 \mathrm{kcal} /$ animal day, or $121.0 \mathrm{kcal} / \mathrm{kg}^{0.75}$ day. This value is similar to that obtained for food I: $30.1 \mathrm{kcal} /$ animal day, or $135.3 \mathrm{kcal} /$ $/ \mathrm{kg}^{0.75}$ day, but at the same time is lower than for food II (Table 3). The mean values of the costs of maintenance for the two types of food are equal to $158 \mathrm{kcal} / \mathrm{kg}^{0.75}$ day. Hence the respirometric determinations are in agreement with the results of the feeding experiments which were carried out in cages of similar size to respirometric chambers. On the other hand, an increased activity of animals in large cages causes the costs of maintenancce to rise by a value considerably deviating from respirometric determinations.

The costs of maintenance determined by food consumption in fat dormouse are, however, very similar to those estimated by this way in other non-hibernating rodents. For example these costs amount to: 167 $\mathrm{kcal} / \mathrm{kg}^{0.75}$ day in gray squirrels ( $\mathrm{L} \mathrm{u} \mathrm{dwick}$, F ontenot \& Mosby, 1969 ) and $152 \mathrm{kcal} / \mathrm{kg}^{0.75}$ day for the water vole (D r o ż d $\dot{z}$ et al., 1971). For small rodents these costs are enclosed within 150 to $220 \mathrm{kcal} / \mathrm{kg}^{0.75}$ day (D r o żd $\dot{z}, 1968$ a).

\subsection{Comparison of DEB of Hibernating and Non-hibernating Rodents}

Since both forest and common dormice are approximately the same size as bank voles (Clethrionomys glareolus) or striped field mice (Apodemus agrarius $\mathrm{Pallas}, 1771$ ) it was possible directly to compare the $D E B$ of these species. On the other hand, the fat dormouse was compared with the northern flying squirrel (Glaucomys sabrinus yukonensis Os good, 1900).

In late spring and early summer the daily energy requirement in the forest dormouse amounts to $0.578 \mathrm{kcal} / \mathrm{g}$ day, in the common dormouse 
to 0.562 , while during the summer in bank voles, it reaches 0.556 (G órecki, 1968), and in striped field mice of similar body weight it is between 0.569 and $0.608 \mathrm{kcal} / \mathrm{g}$ day (G ór e cki, 1969). Similarly, northern flying squirrel $D E B(0.289 \mathrm{kcal} / \mathrm{g}$ day - G rodzińs ki, 1971) and fat dormouse $D E B(0.289 \mathrm{kcal} / \mathrm{g}$ day $)$ are comparable. These data confirm the theory that during activity the energy requirement of the Gliridae is similar to that of other rodents. They are also in agreement with Kalabukhov's (1960) opinion of the metabolic similarity in hibernating and non-hibernating rodents. Nevertheless, a considerable difference exists in physiological mechanisms due to the fact that hibernating rodents are able to switch off « themselves from active life for a certain period of time. This inactivity may last 12 hours or more and may be repeated regularly every day $(\mathrm{Likh}$ a $\mathrm{chev}, 1965$; this paper, Fig. 3), or may be prolonged to several days ( $\mathrm{Likhachev}, 1965$; Walhovd, 1971; authors' observations on common and fat dormice kept in laboratory). Hence in any considerations of energy flow through a population of these animals the fact should be taken into consideration that among hibernating rodents some individuals may be periodically inactive.

The physiological differences of hibernating rodents is also confirmed by considerable seasonal fluctuations of metabolic rate, as distinct from winter sleep. In the three dormouse species investigated autumn oxygen consumption is lower than in the spring-summer period, in some cases by as much as $80 \%$. In non-hibernating rodents, seasonal differences are never so high ( $\mathrm{K}$ a l a b u k hov, 1969).

\subsection{Annual Energy Budget}

Although the daily energy requirement in the period of active life of the Gliridae is similar to that of non-hibernating rodents, the Glirid annual budget is markedly different. The difference arises from the fact that dormice spend a considerable part of the year hibernating, during which the rate of metabolism is several times lower than in the active period (Table 6). Although the data on metabolic rate in forest dormice during winter hibernation are lacking an attempt was made to calculate the annual budget for all three species. The data for forest dormouse were assumed equal to those of common dormouse since these two species show physiological similarities as indicated by metabolic rates in spring-summer and in autumn (cf. Table 1).

The length of the hibernation period is mot constant. Moreover, it was observed that in the periphery of an area inhabited by a given species, the animals may be active all year, e.g., D. nitedula in Israel ( $\mathrm{N} \mathrm{e} \mathrm{vo} \mathrm{\&}$ 
A $\mathrm{m}$ i r, 1961). In central Europe, the Gliridae always fall asleep for 5 to 7 months in winter ( $\mathrm{K}$ owalski, 1964). The length of hibernation depends also on sex and age of animals, adult females enter hibernation first, than adult males, and lastly, young of the year (V i e ting h of f R i es ch, 1960; A ngermann, 1963).

For simplification, of the following calculation, it was assumed that winter hibernation lasts from the beginning of October until the end of March, that is, exactly 181 days. A similar extended period of hibernation is also characteristic for other hibernating rodents, e.g., ground squirrel (Citellus citellus L in n a u s, 1776) sleeps for 186 days a year (K a y s è r, 1953).

For calculating the annual budget it was also assumed that the period of full activity lasts 4 months, from May to August (123 days), while

Table 6

Oxygen consumption and energy requirement in three species of Gliridae during hibernation.

\begin{tabular}{lccc}
\hline & Glis glis & $\begin{array}{c}\text { Muscardinus } \\
\text { avellanarius }\end{array}$ & $\begin{array}{l}\text { Dryomys } \\
\text { nitedula }\end{array}$ \\
\hline No. of measurements & $89^{1}$ & $7^{2}$ & - \\
Avg. body weight, $\mathrm{g}$ & $121.0^{1}$ & $225^{1}$ & $29.3^{2}$ \\
Environmental temp., ${ }^{\circ} \mathrm{C}$ & $9.7^{1}$ & $10.1^{1}$ & - \\
$\mathrm{O}_{2} \mathrm{ccm} / \mathrm{kg} \mathrm{hr}$ & $27.52^{1}$ & $40.0^{1}$ & 0.040 \\
$\mathrm{O}_{2} \mathrm{ccm} / \mathrm{g} \mathrm{hr}$ & 0.027 & 0.040 & 0.004 \\
$\mathrm{kcal} / \mathrm{g} \mathrm{day}$ & 0.003. & 0.004 & 0.117 \\
$\mathrm{kcal} / \mathrm{animal}$ day & 0.368 & 0.099 & .
\end{tabular}

${ }^{1}$ Data after Kayse $\mathrm{K}$ (1961). ${ }^{2}$ Body weight of $D$. nitedula in this period was established after data of Mammals Research Institute at Białowieża. $\mathbf{3}$ Assumed data. ${ }^{4}$ It was assumed that during hibernation $R Q$ equals 0.7 and caloric coefficient of oxygen is $4.6 \mathrm{kcal} / \mathrm{l}$.

April and September ( 30 days each) are the transitory periods. For the latter period data on $D E B$ obtained for summer at $20^{\circ} \mathrm{C}$ were used. This is justified by the fact that the mean temperature in April and September is lower than during the summer months.

Two variants of the annual budget of fat dormouse are presented. In the first one it was assumed that the animals are fully active from May until August, while on the other - that they periodically fall into a state of torpor. In the second variant, calculations were based on the measurements on an individual which was inactive for 15 hours daily (cf. Fig. 3, Table 1). For the common and forest dormouse the energy requirement was calculated only for individuals fully active in summer.

The annual energy budget data of the three species are shown in Table 7. They indicate a striking disproportion of energy consumption during active life and during hibernation. In all three species the con- 
sumption of energy during true hibernation accounts for less than $1 \%$ of the annual budget, although hibernation extend for over $5^{1 / 2}$ months. Even when this value is added to the periods of activity, during which oxygen consumption is much higher, energy consumption during winter hibernation does not exceed $10 \%$ of the annual budget. The remaining $90 \%$ of energy is metabolized during 6 months of active life. It should be also emphasized that the relative distribution of this consumption in

Table 7

Energy consumption in different seasons of the years by fat, common and forest dormice. For Glis glis in the 1st variant it was assumed that the animals are active in the period from April to September, and in the 2nd variant - that they occasionally became torpid (cf. Table 5 ).

\begin{tabular}{|c|c|c|c|c|c|}
\hline $\begin{array}{l}\text { Months } \\
\text { Days }\end{array}$ & April & $\underset{123}{\text { May_August }}$ & $\begin{array}{l}\text { Sept. } \\
30\end{array}$ & $\begin{array}{l}\text { Oct.-March } \\
181\end{array}$ & $\begin{array}{c}\text { Year, total } \\
364\end{array}$ \\
\hline \multicolumn{6}{|c|}{$\begin{array}{c}\text { Glis glis } \\
\text { 1st variant }\end{array}$} \\
\hline$D E B$, kcal & 27.44 & 38.29 & 27.44 & 0.368 & \\
\hline $\mathrm{kcal} / \mathrm{animal}$ & 823.2 & 4709.7 & 823.2 & $61.8^{1}+511.1^{2}$ & 6929.0 \\
\hline Per cent & 11.9 & 68.0 & 11.9 & $0.9+7.3$ & 100.0 \\
\hline \multicolumn{6}{|c|}{ 2nd variant } \\
\hline$D E B, \mathrm{kcal}$ & 27.44 & $23.09^{8}$ & 27.44 & 0.368 & \\
\hline kcal/animal & 823.2 & 2840.1 & 823.2 & $61.8^{1}+511.1^{2}$ & 5059.4 \\
\hline Per cent & 16.3 & 56.1 & 16.3 & $1.2+10.1$ & 100.0 \\
\hline \multicolumn{6}{|c|}{ Muscardinus avellanarius } \\
\hline$D E B, \mathrm{kcal}$ & 7.28 & 10.16 & 7.28 & 0.099 & \\
\hline $\mathrm{kcal} /$ animal & 218.4 & 1249.7 & 218.4 & $16.6^{1}+137.3^{2}$ & 1840.4 \\
\hline Per cent & 11.9 & 67.9 & 11.9 & $0.9+7.4$ & 100.0 \\
\hline \multicolumn{6}{|c|}{ Dryomys nitedula } \\
\hline$D E B, \mathrm{kcal}$ & $11.59^{4}$ & & 11.59 & 0.117 & \\
\hline kcal/animal & 347.7 & 1586.7 & 347.7 & $16.6^{1}+162.5^{2}$ & 2464.2 \\
\hline Per cent & 14.1 & 16.4 & 14.1 & $0.8+6.6$ & 100.0 \\
\hline
\end{tabular}

1 The value of oxygen consumption in the period of true hibernation which lasts 168 days, similarly to that in the ground squirrel ( $\mathrm{K}$ a y s e r, 1953). 2 Amount of energy consumed during 13 days of awakening, when it was assumed that the rate of metabolism is 8.27 times higher (see $\mathrm{K}$ a y s e r, 1953). ' $D E B$ was calculed from ADMR determined in autumn at $20^{\circ} \mathrm{C}$.

particular seàsons is similar in all species (Table 7). Even assuming that fat dormice periodically fall into torpor the proportion of energy consumption during hibernation only slightly exceeds $10 \%$ of the annual budget.

A similarly low energy requirement during winter hibernation is characteristic of other hibernating rodents. K a y s e r (1953) reported that the ground squirrel consumed barely $70 \mathrm{kcal}$ during 171 days of hibernation. This corresponds almost exactly to the value found for the slightly smaller fat dormouse. However, the ground squirrel does not sleep continually, and $579 \mathrm{kcal}$ consumed when the squirrel was awake 
for 14 days should be added to the above-mentioned energy requirement. For this reason the energy requirement düring hibernation in the Gliridae was calculated on the basis of determinations reported by $\mathrm{K}$ a y s e $\mathrm{r}$ (1953). Data on direct determination of these values in Glirids are lacking but we know that these animals hibernate with short periods of awakening ( $\mathrm{P} \circ \mathrm{hl}, 1967$; Kayser, Stussi \& Richert, 1969). Hence the proportion of sleep and periods of awakening, as well as differentiation of the metabolic rate in the calculation of energy budgets for the Gliridae, were assumed to be identical with that of ground squirrel.

During winter dormice consume energy reserves accumulated before hibernation. Assuming that the whole reserve consists of fat having the caloric value of $9 \mathrm{kcal} / \mathrm{g}$, it should be $60 \mathrm{~g}$ in the fat dormouse and 17 and $19 \mathrm{~g}$, respectively, in common and forest dormice. Although under laboratory conditions Pohl (1967) observed that fat dormice sometimes consume food, after awakening, this is unlikely to occur in natural conditions. Thus it should be assumed that for the entire period between October and March, Gliridae accumulate sufficient body tissues reserves. The costs of autumn fat deposition should be added to the calculations. These costs are not high and amount to $3.1 \mathrm{kcal} / \mathrm{g}$ of deposited tissue (cf. Table 3), hence they are within $2-3 \%$ of the annual budget.

The considerable differentiation of energy requirements during the year observed in hibernating rodents constitutes a basic difference between them and non-hibernating rodents having relatively small $D E B$ seasonal fluctuations (G ębczyński, 1966; Grodziński \& Górecki, 1967; G ór ecki, 1968, 1969). Although in certain periods of the year these two groups of small mammals act as similar links in the energy flow chain, their significance in the yearly energy balance is different. From the bioenergetic standpoint is important that energy consumption by dormice is very small in winter, and - even more important - that in this period they utilize reserves accumulated in autumn since they are excluded from their biotopes energy flow then.

In the general energy flow balance the Gliridae may play a considerable role in the biotopes where larger numbers of them live, but of course only in the active period of their life. For example, in linden-oak forests of central Russia the numbers of $M$. avellanarius reach 3.5 individuals per ha ( $\mathrm{L} \mathrm{i} \mathrm{h} \mathrm{h} \mathrm{chev,} \mathrm{1954).} \mathrm{Hence} \mathrm{in} \mathrm{this} \mathrm{case} \mathrm{the} \mathrm{energy} \mathrm{flow}$ through this species approximates $6,000 \mathrm{kcal} / \mathrm{ha}$ per year. All these data emphasize the necessity of taking ciliridae into consideration in studies of energy flow through a mammal population.

Acknowledgement: The authors are indebted to Dr. G. L. Dry den for revising the English text. 


\section{REFERENCES}

1. A ngermann R., 1963: Zur Okologie und Biologie des Baumschläfers, Dryomys nitedula (P a lla s, 1779) in der Waldsteppenzone. Acta theriol., 7, 18: 333 -367 .

2. Drożd ż A., 1968a: Digestibility and assimilation of natural foods in small rodents. Acta theriol., 13, 21: 367-389.

3. Drożd $\dot{z}$ A., 1968b: Studies on digestibility and assimilation of foods in rodents. Ekol. pol., B, 14, 2: 147-159 [In Polish with English summ.].

4. Drożdż A., Górecki A., Grodziński W. \& Pelikan J., 1971: Bioenergetics of water voles (Arvicola terrestris L.) from southern Moravia. Ann. zool. Fennici 8: 97-103.

5. Eis e n tra u t M., 1946: Der Winterschlaf mit seinen ökologischen und physiologischen Begleiterscheinungen. Gustav Fischer: 1-160. Jena.

6. G ębczyński M., 1963: Apparatus for daily measurements of oxygen consumption in small mammals. Bull. Acad. pol. Sci., Cl. II, 11, 9: 433-436.

7. Gębczyński M., 1966: The daily energy requirement of the yellow-necked field mouse in different seasons. Acta theriol., 11, 17: 391-398.

8. G ębczyński M., 1969: Social regulation of body temperature in the bank vole. Acta theriol., 14, 29: 427-.440.

9. Golodushko B. S. \& Padutov E. E., 1961: Materialy k ekologii lesnoj soni v Belovežskoj pušče. Fauna i ekol. nazem̀n. pozvon. Belorussii: 49-70. Minsk.

10. Górecki A., 1968: Metabolic rate and energy budget in the bank vole. Acta theriol., 13, 20: $341-365$.

11. Górecki A., 1969: Metabolic rate and energy budget of the striped field mouse. Acta theriol., 14, 14: 181-190.

12. Grodzinski W., 1971: Energy flow through populations of small mammals in the Alaska taiga forest. Acta theriol., 16, 17: 231-276.

13. Grodziński W. \& Górecki A., 1967: Daily energy budgets of small mammals. [In: „Secondary productivity of terrestrial ecosystems «, ed. K. Petrus e w i c z]. Państw. Wyd. Nauk.: 295-314. Warszawa-Kraków.

14. Holišova V., 1968: Notes on the food of dormice (Gliridae). Zool. Listy, 17, 2: $109-114$.

15. Ka c z marski F., 1966: Bioenergetics of pregnancy and lactation in the bank vole. Acta theriol., 11, 19: 409-417.

16. Kalabukhov N. I., 1960: Comparative ecology of hibernating mammals. Bull. Mus. comp. Zool., 124: 45-74.

17. Ka la bukhov N. I., 1969: Periodičeskie i godičnye izmenenija $\mathrm{v}$ organizme gryzunov, ih pričiny i posledstvija. Izd. Nauka: 1-248. Leningrad.

18. K a y ser Ch., 1939: Les échanges respiratoires des hibernants réveillés. Ann. physiol. physicochim. biol., 15: 1087-1219 (after Kayser, 1965).

19. K a y s e r Ch., 1940: Les échanges respiratoires des hibernants à l'état de sommeil hivernal. Ann. Physiol., 16: 127-221 (after Kayser, 1961).

20. Ka y s e r Ch., 1953: L'hibernation des mammifères. Année biol., 29: 105-150 (after Kayser, 1965).

21. K a y ser Ch., 1961: The physiology of natural hibernation. Pergamon Press: $1-325$ + VII. Oxford-London-New York-Paris.

22. K a y se r Ch., 1965: Hibernation. [In: "Physiological Mammalogy«, eds. W. V. Mayer \& R. G. van Gelder]. Academic Press: 179-296. New York-London. 
23. K a y ser Ch. \& Hildwein G., 1966: Le rythme nycthémeral de la consommation d'oxygène du Loir (Glis glis) à l'état réveillé et actif en autonome. C. $r$. Séanc. Soc. Biol., 160, 5: 1068-1071.

24. K a y s e r Ch., Stussi T. \& R i chert R., 1969: La consommation d'oxygène du Loir (Glis glis) on cours de l'hibernation. C. r. Séanc. Soc. Biol., 163, 1: 212 -214 .

25. Kowa 1 ski K. (ed.), 1964: Klucze do oznaczania kręgowców Polski. V. Ssaki - Mammalia. Państw. Wyd. Nauk.: 1-280. Warszawa-Kraków.

26. Likhachev G. N., 1954: Razmnoženie i čislennost' orešnikovoj soni. Zool. Ž., 33, 5: $1171-1182$.

27. Likhachev G. N., 1965: Materialy po sutočnoj aktivnosti i letnej spiačkie orešnikovoj soni. Bjul. Mosk. Obšč. Ispyt. Prir., Biol., 70, 2: 5-17.

28. Ludwick R. L., Fonten ot J. P. \& M osby H. S., 1969: Energy metabolism of the eastern gray squirrel. J. Wildl. Mgmt., 33, 3: 569-575.

29. Migula P., 1969: Bioenergetics of pregnancy and lactation in European common vole. Acta theriol., 14, 13: 167-179.

30. Morrison P. R. \& Grodziński W., 1968: Morrison respirometer and determination of $A D M R$. [In: "Methods of Ecological Bioenergetics «, eds. W. Grodziński \& R. Klekowski]. Polish Acad. Sci.: 153-163.

31. N evo E. \& A mir E., 1960: Biological observations on the forest dormouse Dryomys nitedula $\mathrm{Pall}$ as in Israel (Rodentia, Muscardinidae). Bull. Res. Counc. Israel, Zool., 9B, 4: 200-201.

32. Os termann K., 1956: Zur Aktivität heimischer Muriden und Gliriden. Zool. Jb., Zool. Physiol., 66, 2/3: 355-388.

33. Pohl H., 1967: Circadian rhythms in hibernation and the influence of light. [In: "Mammalian Hibernation III", eds. K. C. Fisher, A. R. Dawe, C. P. Lyman E. Schönbaum \& F. E. South, Jr.]. Oliver \& Boyd: 140-151: EdinburghLondon.

34. Pielowski Z. \& Wasilewski A., 1960: Haselmäuse in Vogelnistkästen. Ztschr. Säugetierkde, 25: $74-80$.

35. R osický B. \& Kratochvíl J., 1955: Drobni ssavci Tatranského narodního parku. Ochrana Přirody, 10, 2: 3-16.

36. Sa int Girons M. C., 1960: Les variations saisonnières du rythme nycthéméral d'activité chez un Lérot femelle (Eliomys quercinus) en captivité. Mammalia, 24: 177-189.

37. Saint Girons M. C., 1965: On the persistence of circadian rhy'thms in hibernating mammals. [In: "Circadian Clocks", ed. J. Aschoff]. North-Holland Publ. Co.: 321-323. Amsterdam.

38. Saint Girons M. C. \& Lenkiewicz Z., 1965: Variations annuelles de l'activité chez Dryomys nitedula (P a 11 a s, 1778) en captivité. Folia biol., 13, 1: 23-39. Kraków.

39. Smirnov. P. K., 1964: O sutočnoj aktivnosti lesnoj soni. Vestn. Leningrád. Univ., 9, 2: 125-127.

40. South F. E. \& House W. A., 1967: Energy metabolism in hibernation. [In: "Mammalian Hibernation III", eds. K. C. Fisher, A. R. Dawe, C. P. Lyman, E. Schönbaum \& F. E. South, Jr.]. Oliver \& Boyd: 305-324. Edinburgh-London.

41. Trojan P. \& Wojciechowska B., 1967: Resting metabolism rate during pregnancy and lactation in the European common vole - Microtus arvalis (P a 11.). Ekol. pol., A, 15, 44: 811-817. 
42. Vieting off-Riesch A., 1960: Der Siebenschläfer (Glis glis L.). Gustav Fischer: 1-196. Jena.

43. Walhovd H., 1971: The activity of a pair of common dormice Muscardinus avellanarius in conditions of captivity. Oikos, 22: $358-365$.

Accepted, May 20, 1972.

Marek Gębczyński

Mammals Research Institute, Polish Academy of Sciences, Białowieża.

\author{
Andrzej Górecki, Andrzej Drożdż \\ Department of Animal Genetics \\ and Organic Evolution, \\ Jagiellonian University, \\ Kraków 2. Krupnicza 50.
}

\section{Marek GĘBCZYN̂SKI, Andrzej GORECKI i Andrzej DROŻDŻ}

\section{METABOLIZM, ASYMILACJA POKARMU I BIOENERGETYKA TRZECH GATUNKOW GLIRIDAE}

\section{Streszczenie}

Na przełomie wiosny i lata oraz jesienią zmierzono zużycie tlenu u popielicy Glis glis (L in nae us, 1766), koszatki Dryomys nitedula (P a 11 a s, 1779) i orzesznicy Muscardinus avellanarius (Linnaeus, 1758). Dzięki dobowym pomiarom możliwe było nie tylko poznanie średniej wartości zużycia tlenu w różnych sezonach (Tabela 1), ale także dało się ocenić dobowy rytm aktywności u poszczególnych gatunków (Ryc. 2, 3, 5, 6). Zmierzono również u wszystkich trzech badanych gatunków wielkość termoregulacji chemicznej (Ryc. 1, 4). Poza tym na wiosnę oszacowano współczynnik strawności i wielkość wykorzystania pokarmu przez popielice (Tabela 2) a na tej podstawie obliczono zależność pomiędzy asymilacją energii a wzrostem ciężaru ciała (Ryc. 7) oraz bilans energetyczny popielic karmionych orzechami i marchwią (Tabela 3).

Wszystkie te uzyskane dane posłużyły do oznaczenia wielkości dobowego budżetu energetycznego badanych gatunków na wiosnę i jesienią (Tabela 5). W dalszej kolejności dokonano próby skalkulowania rocznego budżetu energetycznego Gliridae (Tabela 7), przy czym wartość metabolizmu w czasie hibernacji przyjęto według danych $\mathrm{z}$ literatury (Tabela 6 ).

Stwierdzono, że ogromne zróżnicowanie zapotrzebowania energetycznego w ciągu roku, jakie obserwuje się u gryzoni hibernujących stanowi podstawową różnicę między nimi a gryzoniami nie zapadającymi w sen zimowy, u których sezonowe wahania tej wartości są względnie male. Choć więc latem obie te grupy drobnych ssaków działają jako podobne ogniwa w lańcuchu przepływu energii, to w przekroju rocznym znaczenie ich jest inne. $\mathrm{Z}$ bioenergetycznego punktu widzenia ważne jєst nie tylko to, że zimą zużycie energii przez Gliridae jest małe, gdyż nie osiąga nawet $10 \%$ calej wartości rocznej, ale istotny jest fakt, że w tym czasie spalają one zapasy nagromadzone jesienią. Zwierzęta te są więc zimą wyłączone $\mathrm{z}$ przepływu energii w zamieszkiwanym przez nie biotopie. 